International Journal of Social Science And Human Research

ISSN(print): 2644-0679, ISSN(online): 2644-0695

Volume 05 Issue 01 January 2022

DOI: 10.47191/ijsshr/v5-i1-26, Impact factor-5.586

Page No: 179-182

\title{
Optimization of the Synergy of the TNI, Polri and Ministry/Institutions in Managing Papua Terrorist Groups to Realize Indonesia's Integrity
}

\author{
Rantau Isnur Eka ${ }^{1}$, Rizerius Eko Hadisancoko ${ }^{2}$, Lukman Yudho Prakoso ${ }^{3}$ \\ 1,2,3 Military Strategy and Campaign Study Program, Faculty of Defense Strategy \\ Defense University of Republic Indonesia, Kawasan Indonesia Peace and Security Center (IPSC) Sentul Bogor Jawa Barat
}

\begin{abstract}
The security situation in Papua has recently escalated and tends to heat up. Responding to the escalation and violence that occurred in Papua, ensure that the government has categorized the Papuan Armed Criminal Group and all organizations and people who are members of it, and who support the movement, as terrorists. The increasing security situation in the Papua region is an urgency for the need for a comprehensive approach between the TNI, Polri, Satkowil, Regional Government, Ministry and Institutions to synergize in order to reduce the Papua conflict. The theory used in analyzing this problem is the theory of optimization, synergy, counter insurgency, the concept of terrorism, and the concept of national defense. The method that the researcher uses is a qualitative method with a phenomenological approach, based on the researcher's experience while on duty in Papua. The results of this study indicate that synergies between institutions / ministries have been carried out in the form of dialogue, a soft power approach within the OMSP framework, as well as empowerment of local communities by synergizing with local governments. However, with the ongoing conflict and several escalations that occur, this shows that the synergy is still not optimal enough.
\end{abstract}

KEYWORDS: Papua, Synergy, Terrorists, Ministries/Agencies, Armed Criminal Groups

\section{INTRODUCTION}

Indonesia is one of the countries in the world that is blessed with a pluralistic society and has ethnic heterogeneity. This diversity is horizontally marked by the fact that there are social units based on differences in ethnicity, religion, customs and primordialism. With such a complex social structure, Indonesia is faced with the potential threat of inter-ethnic conflict, social inequality and challenges to the integrity of the Unitary Republic of Indonesia. In order to maintain the territorial integrity of the Unitary State of the Republic of Indonesia as a sovereign nation and state, the Indonesian National Armed Forces (TNI) as the main component of the National Defense System together with the people have carried out several national defense efforts. This effort started from the suppression of the rebellion in the PKI incident in Madiun (1948), the DI/TII rebellion (1950), the Liberation of West Irian (1961), Operation Dwikora (1963), the suppression of the G30S/PKI (1965), and Operation Seroja (1974-2014). 1999) [1]

The security situation in Papua has recently escalated and tends to heat up. Various demonstrations against the special autonomy status (Otsus) and shooting incidents due to armed conflict continue to take lives, from civilians, community leaders to security forces. In relation to this armed contact, the TNI had released that it was carried out by the Terrorist Group, the designation attached to the West Papua National Liberation Army-Free Papua Organization (TPNPB-OPM) aimed at seeking attention for the UN General Assembly. Then, in September 2020 a number of demonstrations against Otsus were also rampant in Papua, one of which was demonstrations against the implementation of Papua's Special Autonomy Volume II around Cendrawasih University, Jayapura, Papua.

From the various problems that have occurred in Papua and several descriptions of the approaches that can be taken in the region, it can be seen that the synergy between institutions, in this case the related Ministries/Agencies, the Police and the TNI, is something that is needed in Papua. Through this approach, it is hoped that conflict resolution in the region can be optimal and comprehensive, so that it can touch the root causes of the conflict. As referring to the concept of the Indonesian state defense system which adheres to the universal people's defense and security system (sishankamrata), in this case the TNI and the Indonesian National Police play an important role as the main force and the people as a supporting force.[2] This Sisnhamkarata in its implementation involves all elements in order to realize national defense. In the case of the Papua issue, the implementation of the Sishankamrata can be realized through synergy between institutions, including the TNI, Polri, and Ministries/Institutions in an effort to establish the integrity of the Unitary State of the Republic of Indonesia in Papua. This is what the researcher discusses and analyzes in the next section. 


\section{Optimization of the Synergy of the TNI, Polri and Ministry/Institutions in Managing Papua Terrorist Groups to Realize Indonesia's Integrity}

\section{METHOD AND THEORY}

This research uses qualitative research. Qualitative methods put more emphasis on observing phenomena and examining the substance of the meaning of these phenomena. The analysis and sharpness of qualitative research is greatly affected by the strength of the words and sentences used. Therefore, Sugiyono explained that the focus of qualitative research is on the process and the meaning of the results. Qualitative research attention is more focused on human elements, objects, and institutions, as well as the relationship or interaction between these elements, in an effort to understand an event, behavior, or phenomenon [4].

This theory is used to analyze actions, processes, or methodologies by the TNI, Polri, and Ministries/Agencies in overcoming the ongoing conflict in Papua. This theory is needed to analyze the significance and indicators of the success of the synergy between the Police and Ministries/Institutions in their efforts to resolve the conflict in Papua through a security and welfare approach. Thus, the research results can identify whether the efforts of the apparatus together with $\mathrm{K} / \mathrm{L}$ can be realized in accordance with the objectives. According to A.F. Stoner and Charles Wankel [3], the best level of cooperation is synergistic, namely high cooperation, mutual trust, and integrated so as to produce an output that is greater than the sum of the performance results of each party. According to Stephen Covey [5], synergy is defined as a creative process that is realized when two parties jointly negotiate and brainstorm to reach a solution.

\section{ANALYSIS AND DISCUSSION}

The role of the TNI and POLRI in eradicating terrorism in Papua in an effort to maintain the sovereignty of the Republic of Indonesia is viewed from the perspective of policy-oriented criminal law reform and at the same time a value-oriented approach, but must prioritize the principle of law enforcement. Orientation to policy can be seen in the formation of Law Number 5 of 2018 concerning the Eradication of Criminal Acts of Terrorism, and the issuance of a Presidential Regulation that regulates the involvement of the TNI in eradicating terrorism. The value orientation is that the involvement of the TNI and POLRI is based on the consideration that the criminal acts of terrorism that have occurred in Indonesia so far are serious crimes that endanger state ideology, state security, state sovereignty, values, humanity and various aspects of social and national life. and state as well as cross-country, organized and have a wide network and have a specific purpose.[6]

Apart from the economic approach, what is more urgent is that the government must solve the root causes of the Papuan conflict, which are still unresolved. This is consistent with theories of counterinsurgency or suppression of rebellion, which see that the root cause of insurgency is usually not only related to politics or territory. Moreover, a rebellion tends to develop in conditions of ideological, religious, ethnic, cultural, and economic repression [7]. Therefore, countries that carry out counterinsurgency must use strategies and programs to win people's support in defeating the rebellion (winning hearts and minds) to legitimize the influence of the state. As formulated by the French counterinsurgency expert, David Galula, the ideal counterinsurgency is 20\% military action and $80 \%$ political to win the people's support.19 Excessive use of military force tends to be counterproductive, because it can cause civilian casualties and reduce the legitimacy of the government.[8]

The National Police themselves since 2019 until now have issued 3 (three) Warrants of Assignment to maintain the security situation and public order in the Papua region with the operating code Nemangkawi in the context of law enforcement against security disturbances caused by armed criminal groups (KKB) [9]. The series of security disturbances in the form of terror bombs, kidnappings, killings of security forces and the public including the destruction and burning of public facilities that occurred in the Papua region, along with attacks on police headquarters in Papua, illustrates how vulnerable and difficult the police task is carried out by the Papuan Police. assisted by other BKO units such as the Korbrimob Polri in realizing Polri's accountability as state law enforcement officers, professional and reliable public servants and protectors.[10]

Referring to Article 15 paragraph 1 letter (b) of the Police Law which states that in carrying out its duties, the State Police of the Republic of Indonesia has the authority to assist in resolving community disputes that may disrupt public order. Efforts to resolve disputes or conflicts themselves have been regulated in the Law on Social Conflict Management, which include: stopping physical violence; determination of State of Conflict Status; and emergency rescue and victim protection measures; and/or assistance in the use and deployment of TNI forces[11]. In this context, the synergy between the TNI and Polri is an important point for the success of security operations in Papua.[12]

In order to optimize the cooperation between the TNI and Polri in handling the Papua issue, there are several things that can be improved. First, increasing stakeholder support for the involvement of the TNI-Polri, through the preparation and issuance of regulations as guidelines governing the duties of the TNI-Polri in dealing with KKB in Papua, increasing common understanding regarding the task of handling KKB in Papua, carrying out the fulfillment of facilities and infrastructure, using this method. determination, study, coordination, instruction, preparation, publication, evaluation, proposal, discussion, revision, ratification, socialization, and cooperation as well as using facilities in the form of joint meetings, configuration cooperation formats, cooperation with relevant ministries, universities, social conflict observer groups in the context of achieve the goal of realizing increased stakeholder support for the involvement of the TNI-Polri in handling KKB in Papua.[13] 


\section{Optimization of the Synergy of the TNI, Polri and Ministry/Institutions in Managing Papua Terrorist Groups to Realize Indonesia's Integrity}

Second, increasing the synergy of operational concepts held by the TNI-Polri Task Force, through the formulation of mechanisms, implementing coordination, integration, synchronization and synergy between the TNI-Polri programs in handling KKB in Papua, increasing cooperation between the Action Task Force, the Gakkum Task Force, and the Public Relations Task Force, using this method. coordination, counseling, communication, cooperation and socialization by using facilities in the form of coordination meetings, joint training, integrated education in order to achieve the goal of realizing increased synergy in the concept of operations held by the TNI-Polri Task Force for handling KKB in Papua [14].

Third, the application of the soft power approach used by the TNI-Polri, through streamlining the history of the entry of Papua into Indonesia, carrying out counter-propaganda activities and the internationalization of Papua with the methods of coordination, counseling, communication, cooperation and socialization using facilities in the form of joint meetings, educational institutions, social communities. creativity, policies and regulations, political education and discussion forums in order to achieve the goal of realizing the application of the soft power approach used by the TNI-Polri in handling KKB in Papua [15].

Lastly, namely increasing the collaboration of the TNI-Polri role with social institutions in community empowerment, through increasing national insight to the Papuan people, increasing TNI-Polri education and social institutions in Papua with methods of communication, coordination, education, discussion, revision, socialization, and evaluation., using facilities in the form of foster parent programs, community forums, NKRI mass organizations in Papua, youth organizations, fostered villages and third parties in order to achieve the goal of realizing increased collaboration between the TNI-Polri role with social institutions in community empowerment for handling KKB in Papua.

\section{CLOSING}

Based on the discussion that has been described in previous chapters, it can be concluded as follows:

a. The results of the research above show that the synergy between the Indonesian National Armed Forces and the Indonesian National Police with other components of the nation is currently being held in the form of a dialogue between the ministry and endidi. Then there is the handling of soft power that is used by the TNI-Polri as a form of collaboration within the framework of the TNI OMPS, and the endidik link between the central government and the endidi regions with the local community in the form of empowerment. However, the synergy between the TNI and Polri with all other components of the nation is still unable to deal with the threat of KKB in Papua.

b. The synergy of the operational concepts held by the TNI-Polri Task Force in dealing with the threat of KKB in Papua has not been optimally established. This is because the communication pattern that has just been established between the TNI-Polri Task Force is only respectful communication. So that the Action Task Force, the Gakkum Task Force, and the Public Relations Task Force still tend to stand on their own. As a result of the lack of synergy in the operational concept held by the TNI-Polri Task Force, it will become an obstacle in achieving the main targets so that its implementation will miss the planned time. Thus, the handling of the KKB threat carried out by the TNI-Polri and other components of the nation so far, has not touched the subject matter, including overcoming the factors causing the Papuan conflict itself. In this case, increasing the synergy of the operational concept held by the TNI-Polri Task Force is an important solution that must be immediately realized by the Government in an effort to deal with the threat of KKB. This solution is realized through increasing the synergy of operational concepts held by the TNI-Polri Task Force, through the formulation of mechanisms, implementing coordination, integration, synchronization and synergy between the TNI-Polri programs in handling KKB in Papua, increasing cooperation between the Action Task Force, the Gakkum Task Force, and the Public Relations Task Force. with the methods of coordination, counseling, communication, education and socialization by using the means of coordination meetings, endidi endidi, integrated education in order to achieve the goal of realizing an increase in the synergy of the operational concept held by the TNI-Polri Task Force for handling KKB in Papua.

\section{REFERENCES}

1) Kep Panglima TNI Nomor Kep/555/VI/2018 tentang Doktrin TNI Tri Dharma Eka Karma.

2) Undang-Undang Republik Indonesia Nomor 3 Tahun 2002 tentang Pertahanan Negara

3) Scott Moore. (2007). The Basics of Insurgency dalam http://smallwarsjournal.com, 8 September 2007., accessed on 12 Mei 2021.

4) Chauvel, D. (2005). Constructing Papua Nationalism: History, Etnicity and Adaptation. Washington: East-West Center.

5) Sugiyono. (2018). Metode Penelitian Kombinasi (Mix Methods). Bandung: Alfabeta.

6) Sugiyono. (2018). Metode Penelitian Kombinasi (Mix Methods). Bandung: Alfabeta.

7) Dipua, A., Harahap, N., Puspitawati, D., Aminuddin, F., Prakoso, L. Y., Brawijaya, U., \& Pertahanan, U. (2021). Sea Defense Strategy the Indonesian Navy in Dealing with the South China Sea Conflict. ITALIENISCH, 11(2), 120-126. https://doi.org/https://doi.org/10.1115/italienisch.v11i2.103 
8) Harris, A., Prakoso, L. Y., \& Sianturi, D. (2019). Strategi Pertahanan Laut dalam Rangka Ancaman Keamanan di Alur Laut Kepulauan Indonesia II. Journal of Social and Political Sciences, Vol.4 No.2 (2021), 5(1), 15-30. https://doi.org/10.31014/aior.1991.04.02.283

9) Junaidi, M. E., Prakoso, L. Y., Eka, M., \& Yudho, L. (2021). Pancasila as the Basis for Indonesia's Universal Defense. Journal of Social and Political Sciences, 4(2), 148-154. https://doi.org/10.31014/aior.1991.04.02.283

10) Kasih Prihantoro, Arif Darmawan, Zakariya ., Lukman Yudho Prakoso, \& Kasih Prihantoro Zakariya ., Lukman Yudho Prakoso, A. D. (2019). Implementation Study of Public Policies, Synergity of Policy for Defense Area and National Area Spatial in Grati Pasuruan. Public Policy and Administration Research, 9(Public Policy and Administration Researc), 3339. https://doi.org/10.7176/PPAR/9-11-04

11) Arief, R., Prakoso, L. Y., \& Risman, H. (2021). UNDERSTANDING NATIONAL IDENTITY TO CREATE LOVE AND PROUD OF BEING A PART OF THE INDONESIAN NATION. Jurnal Inovasi Penelitian, 1(11), $2549-2556$. https://doi.org/https://doi.org/10.47492/jip.v1i11.518

12) Lukman Yudho Prakoso, Suhirwan, Kasih Prihantoro, Asep Iwa Soemantri- Editor: Budi Pramono, R. (2021). Bahan Ajar Kebijakan Pertahanan Laut (R. Budi Pramono (Ed.); 1st ed.). Unhan Press

13) Madrohim, M., Prakoso, L. Y., \& Risman, H. (2021). Journal of Social and Pancasila Revitalization Strategy in the Era of. Journal of Social and Political Sciences, Vol.4 No.2 (2021), 4(2), 155-164. https://doi.org/10.31014/aior.1991.04.02.284

14) Lebo, D., Midhio, I. W., \& Prakoso, L. Y. (2021). Comparison of The Indonesia Guerrilla War In The Perspective of The Universal War. Journal Of Sosiasl Sciense, 2. https://doi.org/https://jsss.co.id/index.php/jsss/article/view/122

15) Kusuma, A. W., Lukman Yudho Prakoso, \& Sianturi, D. (2021). THE COOPERATION BETWEEN FLEET I COMMAND AND INDONESIAN MARITIME SECURITY AGENCY IN ELIMINATING TRANSNATIONAL CRIME IN THE MALACCA STRAIT. International Journal of Education and Social Science Research, 4(03), 51-61. https://doi.org/: http://dx.doi.org/10.37500/IJESSR.2021.4305 